\title{
PENGARUH E-SERVICE QUALITY TERHADAP E-CUSTOMER SATISFACTION WEBSITE START-UP KAOSYAY
}

\author{
Faruk Ulum ${ }^{1)}$, Rinaldi Muchtar ${ }^{2}$ \\ ${ }^{1,2)}$ Sistem Informasi, Universitas Teknokrat Indonesia \\ ${ }^{1,2)}$ Jl. H.Zainal Abidin Pagaralam, No.9-11, Labuhanratu, Bandarlampung \\ Email:faruk.ulum@teknokrat.ac.id ${ }^{1)}$,damalapaksi13@gmail.com ${ }^{2)}$
}

\begin{abstract}
Abstrak
Pertumbuhan pesat pangsa pasar e-commerce di Indonesia memang sudah tidak bisa diragukan lagi. Untuk menghadapi intensitas tantangan yang semakin berat, perusahaan dalam menjalankan bisnisnya dituntut berfikir kreatif dalam menemukan berbagai terobosan strategi yang mampu menciptakan sinergi sehingga memberikan kontribusi optimal bagi pencapaian tujuan perusahaannya. maka penting diadakannya penelitian untuk mengetahui bagaimana pengaruh kualitas layanan terhadap kepuasan pelanggan pada pelanggan situs berbelanja online kaosyay.com Penelitian ini dilakukan untuk mengukur penilaian pelanggan terhadap variabel eservice quality dan e-customer satisfactio, mengevaluasi pengaruh variabel e-service quality dan e-customer satisfaction. Jenis penelitian yang digunakan pada penelitian ini adalah deskriptif kausal. Item kuesioner yang digunakan sebanyak 28 item. Pengumpulan data dilakukan dengan cara penyebaran kuesioner kepada pengguna dari situs berbelanja online kaosyay.com yang telah mengakses kaosyay dengan jumlah sampel sebanyak 30 orang yang ditentukan dengan metode nonprobability purposive sampling. Teknik analisis data yang digunakan adalah Structural Equation Model dengan tingkat signifikansi 5\%. Hasil yang diperoleh pada penelitian ini adalah e-service quality berpengaruh positif dan signifikan terhadap e-customer satisfaction.
\end{abstract}

Kata Kunci : E-Service Quality, E-Customer Satisfaction, Start-Up Kaosyay.

\section{Pendahuluan}

Website adalah penggunaan atau penerapan suatu konsep yang menjadi pokok pembahasan. Website dapat diartikan juga sebagai program komputer yang dibuat untuk menolong manusia dalam melaksanakan tugas tertentu (Agus Hermawan, 2006 : 100). Website merupakan informasi deskriptif pada salinan tercetak dan bentukbentuk maya yang menggambarkan pengoperasian dan penggunaan program-program (Roger S, 2010). Website adalah kumpulan dari halaman-halaman situs, yang biasanya terangkum dalam sebuah domain atau subdomain, yang tempatnya berada di dalam World Wide Web (www) di Internet.

Sebuah web page adalah dokumen yang ditulis dalam format HTML (Hyper Text Markup Language), yang hampir selalu bisa diakses melalui HTTP. Semua publikasi dari website-website tersebut dapat membentuk sebuah jaringan informasi yang sangat besar. Web page layaknya sebuah buku yang dapat menampung berbagai informasi tentang banyak hal baik bersifat komersil maupun non komersil. Melalui media web inilah seseorang dapat memberikan informasi tertentu kepada orang lain yang berada di seluruh dunia. (Dodit Suprianto \& Rini Agustina, 2012).

Pemilihan website sendiri dilatar belakangi oleh tingginya pengguna perangkat komputer di Indonesia sebanyak 63,1 juta pengguna dan merupakan perangkat dengan jumlah pengguna tertinggi dari perangkat tertinggi dibandingkan perangkat lainnya (APJII,2016). Website yang banyak diakses dan sering digunakan salah satunya dari bidang ekonomi yaitu online shop. Start-Up kaosyay merupakan salah satu perusahaan rintisan penyedia kaos jadi maupun kaos pemesanan sesuai kebutuhan. Start-Up ini menggunakan website e-commerce atau online shop dalam menjalankan bisnisnya. Sebagai start-up e-commerce yang masih dalam proses perkembangan harus diimbangi dengan kualitas layanan yang baik agar perkembangan start-up ini dapat terus meningkat kedepannya.

Kualitas layanan atau e-service quality yang akan ditanamkan kedalam website ini berperan sangat penting untuk para pelanggan kaosyay. E-service quality adalah sebuah bentuk kualitas layanan yang lebih luas dengan media internet yang menghubungkan antara penjual dan pembeli untuk memenuhi kegiatan berbelanja secara efektif dan efisien (Chase, Jacobs, \& Aquilano, 2013). Eservice quality yang bertugas sebagai variabel bebas (independent) ini akan dipakai nanti menggunakan model service quality. Model tradisional ini telah dikembangakan dari lima dimensi menjadi tujuh dimensi diantaranya adalah efisiensi, reliabilitas, fulfillment, privasi, daya tanggap, kompensasi dan kontak. Tiga dimensi utamanya adalah efisiensi, reliabilitas dan fulfillment (Fandy Tjiptono dan Greorius Chandra, 2016).

Dalam pembuatannya website ini akan diintegrasikan kembali dengan e-customer satisfaction yang notabennya adalah variabel terikat (dependent) yang mempunyai 3 dimensi utama instrumen diantaranya adalah $e$-commerce customer satisfaction, eTail, dan website user satisfaction yang berkaitan dengan 3 dimensi utama e-service quality (Fandy Tjiptono dan Greorius Chandra, 2016). Dengan adanya $e$-service quality dan e-customer satisfaction dapat meningkatkan jumlah calon konsumen. 


\section{Landasan Teori}

Service Quality adalah seberapa jauh sebuah website memfasilitasi pembelanjaan yang efektif dan efisien, pembelian, dan penyampaian produk atau jasa. Berdasarkan definisi kualitas layanan, dapat ditarik kesimpulan bahwa kualitas layanan adalah metode untuk mengukur kepuasan pelanggan dari sebuah penyedia layanan berbasis internet meliputi pembelanjaan, dan penyampaian produk atau jasa. Pengukuran tersebut dilakukan dengan mengukur bagaimana jasa yang dirasakan oleh pelanggan dan membandingkanyna dengan jasa yang diharapkan pelanggan berdasarkan pada dimensi-dimensi tertentu dari sebuah kualitas layanan (Fandy Tjiptono dan Greorius Chandra, 2016). Menurut Zeithaml, et al. (2002) mengidentifikasi tujuh dimensi yang membentuk skala "core online service" dan skala "recovery online service". Tiga dimensi utama (efisiensi, reliabilitas, dan fulfillment) merupakan skala inti e-service quality yang digunakan untuk mengukur persepsi pelanggan terhadap kualitas jasa yang disampaikan pengecer online. Dimensi-dimensi ini meliputi pula kriteria yang digunakan pelanggan untuk mengevaluasi layanan online rutin manakala mereka tidak mengalami masalah sehubungan dengan penggunaan situs tertentu. Sementara itu, 4 dimensi lainnya (privasi, daya tanggap, kompensasi, dan kontak) merupakan skala recovery e-service quality. Maksudnya, dimensi-dimensi ini hanya berperan penting dalam situasi pelanggan online mengalami masalah atau memiliki sejumlah pertanyaan yang ingin dicarikan solusinya. Secara ringkas, ketujuh dimensi e-service quality meliputi:

\section{Efisiensi}

Kemampuan pelanggan untuk mengakses website, mencari produk yang diinginkan dan informasi yang berkaitan dengan produk tersebut, serta meninggalkan situs bersangkutan dengan upaya minimal.

\section{Reliabilitas}

Berkenaan dengan fungsionalitas teknis situs bersangkutan khususnya sejauh mana situs tersebut tersedia dan berfungsi sebagaimana mestinya.

\section{Fulfillment (jaminan)}

Mencakup akuransi janji layanan, ketersediaan stok produk, dan pengiriman produk sesuai waktu yang dijanjikan

\section{Privasi}

Jaminan bahwa data perilaku berbelanja tidak akan diberikan kepada pihak lain.

\section{Daya Tanggap}

Kemanapun pengecer online untuk memberikan informasi yang tepat kepada pelanggan sewaktu timbul masalah, memiliki mekanisme untuk menangani pengembalian produk, dan menyediakan garansi online.

\section{Kompensasi}

Meliputi pengembalian uang, biaya pengiriman, dan biaya penanganan produk.

\section{Kontak}

Mencerminkan kebutuhan pelanggan secara online atau melalui telepon.

Menurut Kotler dan Keller (2006) menyatakan bahwa "Customer Satisfaction is a person's feeling of pleasure or disappointment resulting from comparing a product's perceived performance (or outcome) in relation to his or her expectations". Dari uraian tersebut, dapat ditarik kesimpulan bahwa kepuasan pelanggan merupakan respon dari pelanggan baik perasaan senang maupun kecewa yang ditunjukkan pelanggan atas barang atau jasa yang diperoleh dan digunakannya. Tingkat kepuasan konsumen mencerminkan bagaimana berhasil dan efektif perusahaan mengimplementasikan kegiatan usahanya. E-customer satisfaction, dalam nada yang sama, mengacu pada "kepuasan pelanggan terhadap pengalaman pembelian sebelumnya" dengan sebuah website. Lebih lanjut, khusus dalam konteks $e$-customer satisfaction telah dikembangkan sejumlah skala pengukuran untuk mengindentifikasi faktor-faktor yang mendorong pelanggan untuk mengunjungi sebuah website dan memicu mereka untuk menggunakan kembali situs bersangkutan. Hal ini amat penting mengingat bahwa begitu banyaknya bermunculan situs baru setiap waktu. Beberapa instrumen pengukuran $e$ customer satisfaction antara lain:

\section{User information satisfaction}

Meliputi staf pemrosesan data elektronik, produk informasi layanan, dukungan vendor, produk, pengetahuan, atau keterlibatan informasi.

\section{End user computing satisfaction}

Terdiri atas konten, akurasi, format, kemudahan penggunaan, dan ketepatan waktu.

\section{Customer information satisfaction}

Terdiri dari dukungan pelanggan, keamanan, kemudahan penggunaan, produk/jasa digital, transaksi dan pembayaran, kontak informasi, dan inovasi.

\section{Sitequal}

Mencakup kemudahan penggunaan, desain estesis, kecepatan pemrosesan, dan keamanan.

\section{E-commerce customer satisfaction}

Meliputi informasi produk, layanan pelanggan, waktu dan biaya pengiriman dan pembelian, desain situs, proses pembelian, metode pembayaran, dan kemudahan penggunaan.

\section{Webqual}

Terdiri atas usability, informasi, dan interaksi layanan

\section{User-perceived web quality}

Mencakup konten spesifik, kualitas konten, penampilan, dan technical adequacy.

\section{Web customer satisfaction}

Meliputi understandability, reliability, usefullness, akses, usability, dan navigasi.

9. eTail

Terdiri atas desain website, fulfillment, reliability, privacy, security, dan layanan pelanggan.

\section{Web site user satisfaction}


Mencakup relevansi informasi, akurasi informasi, kemudahan penggunaan, kecepatan koneksi, layout, bahasa, dan customization.

\section{1. eTranQual}

terdiri atas funcionality desain, enjoyment, proses, reliabilitas, dan responsivitas.

Model konseptual yang digunakan pada penelitian ini digambarkan di bawah ini.

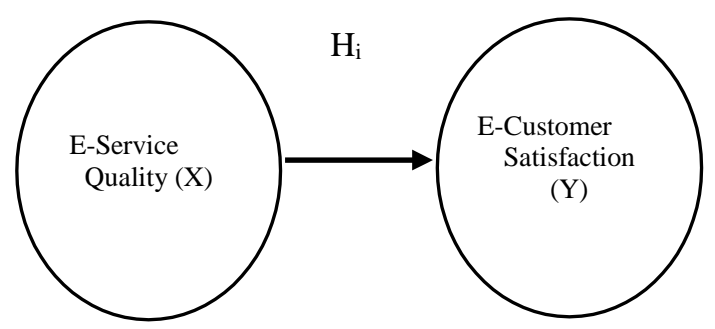

Gambar 1. Model Konseptual

Hipotesis yang digunakan dalam penelitian ini adalah $e$ service quality dengan dimensi realibilitas berpengaruh positif terhadap $e$-customer satisfaction dengan dimensi $e$ commerce customer satisfaction pada website kaosyay.

\section{Metode Penelitian}

Metode penelitian yang digunakan dalam penelitian ini adalah kuantitatif karena menurut Sugiyono penelitian kuantitatif dapat diartikan sebagai metode penelitian yang berlandaskan pada filsafat positivisme, digunakan untuk meneliti pada populasi atau sampel tertentu, teknik pengambilan sampel pada umumnya dilakukan secara random, pengumpulan data menggunakan instrumen penelitian, analisis data bersifat kuantitatif/statistik dengan tujuan untuk menguji hipotesis yang telah ditetapkan.

\subsection{Metode Pengumpulan Data}

Metode pengumpulan data yang dilakukan dalam penelitian ini adalah kuesioner. Menurut Arikunto (2002), kuesioner adalah sejumlah pertanyaan tertulis yang digunakan untuk memperoleh informasi dari responden dalam arti laporan tentang pribadinya atau hal-hal yang diketahuinya.

\subsection{Teknik Analisis Data}

Analisis data dilakukan dengan menggunakan analisis regresi linear sederhana. Sebelum itu perlu dilakukan uji validasi dan reliabilitas terlebih dahulu yang selanjutnya di lakukan proses uji asumsi klasik sebagai syarat terlaksananya analisis regresi linear sederhana. Secara sederhana, penelitian ini menggunakan teknik analisis data sebagai berikut:

1. Uji Statistik Deskriptif Kuesioner

2. Uji Validitas

3. Uji Reliabilitas

4. Uji Normalitas

5. Uji Linearitas

6. Uji Heteroskedastisitas

7. Analisis Regresi Linear Sederhana

\section{Uji Koefisien Determinasi}

9. Uji Statistik F

\section{Hasil dan Pembahasan}

\subsection{Statistik Deskriptif Kuesioner}

Tabel 1 Statistik Deskriptif Kuesioner

\begin{tabular}{|c|c|c|c|c|}
\hline Variabel & Minimum & Maximum & $\begin{array}{l}\text { Rata- } \\
\text { Rata }\end{array}$ & $\begin{array}{c}\text { Standar } \\
\text { Deviasi }\end{array}$ \\
\hline $\begin{array}{l}\text { E-Service } \\
\text { Quality, } \\
\text { Reliabilitas } \\
\text { (X) }\end{array}$ & 34 & 63 & 49,27 & 6,992 \\
\hline $\begin{array}{l}\text { E-Customer } \\
\text { Satisfaction, } \\
\text { E- } \\
\text { Commerce } \\
\text { Customer } \\
\text { Satisfaction } \\
\text { (Y) }\end{array}$ & 36 & 64 & 49,73 & 7,611 \\
\hline $\begin{array}{l}\text { Valid (N) } \\
\quad \text { Listwise }\end{array}$ & 30 & & & \\
\hline
\end{tabular}

Berdasarkan tabel 4.1, diketahui bahwa terdapat dua variabel penelitian (E-Service Quality dan E-Customer Satisfaction) dengan jumlah sampel secara keseluruhan sebanyak 30 responden. Dengan nilai minimum sebagai nilai terendah untuk setiap variabel, dan nilai maksimum untuk nilai tertinggi untuk setiap variabel dalam penelitian. Dalam tabel juga dapat dilihat mean dari setiap nilai dari masing-masing variabel. Selain itu juga dapat dilihat standar deviasi nilai dari data masing-masing variabel.

\subsection{Uji Validitas}

Tabel 2 Uji Validitas E-Service Quality

\begin{tabular}{|c|c|c|c|}
\hline Instrumen & $\begin{array}{r}\text { rhitung (pearson } \\
\text { correlation) }\end{array}$ & $\begin{array}{c}\text { rtabel 5\% } \\
\mathbf{( 3 0 )}\end{array}$ & Keterangan \\
\hline $\mathrm{X} 1$ & 0,566 & 0,349 & VALID \\
\hline $\mathrm{X} 2$ & 0,569 & 0,349 & VALID \\
\hline $\mathrm{X} 3$ & 0,607 & 0,349 & VALID \\
\hline $\mathrm{X} 4$ & 0,503 & 0,349 & VALID \\
\hline $\mathrm{X} 5$ & 0,451 & 0,349 & VALID \\
\hline $\mathrm{X} 6$ & 0,511 & 0,349 & VALID \\
\hline $\mathrm{X} 7$ & 0,532 & 0,349 & VALID \\
\hline $\mathrm{X} 8$ & 0,601 & 0,349 & VALID \\
\hline $\mathrm{X} 9$ & 0,672 & 0,349 & VALID \\
\hline $\mathrm{X} 10$ & 0,565 & 0,349 & VALID \\
\hline $\mathrm{X} 11$ & 0,822 & 0,349 & VALID \\
\hline $\mathrm{X} 12$ & 0,689 & 0,349 & VALID \\
\hline $\mathrm{X} 13$ & 0,727 & 0,349 & VALID \\
\hline $\mathrm{X} 14$ & 0,658 & 0,349 & VALID \\
\hline
\end{tabular}


Tabel 3 Uji Validitas E-Customer Satisfaction

\begin{tabular}{|c|c|c|c|}
\hline Instrumen & $\begin{array}{c}\text { rhitung (pearson } \\
\text { correlation) }\end{array}$ & rtabel 5\% (30) & Keterangan \\
\hline Y1 & 0,495 & 0,349 & VALID \\
\hline Y2 & 0,558 & 0,349 & VALID \\
\hline Y3 & 0,679 & 0,349 & VALID \\
\hline Y4 & 0,510 & 0,349 & VALID \\
\hline Y5 & 0,532 & 0,349 & VALID \\
\hline Y6 & 0,674 & 0,349 & VALID \\
\hline Y7 & 0,661 & 0,349 & VALID \\
\hline Y8 & 0,722 & 0,349 & VALID \\
\hline $\mathrm{Y} 9$ & 0,600 & 0,349 & VALID \\
\hline $\mathrm{Y} 10$ & 0,529 & 0,349 & VALID \\
\hline Y11 & 0,773 & 0,349 & VALID \\
\hline Y12 & 0,573 & 0,349 & VALID \\
\hline $\mathrm{Y} 13$ & 0,720 & 0,349 & VALID \\
\hline Y14 & 0,702 & 0,349 & VALID \\
\hline
\end{tabular}

\subsection{Uji Reliabilitas}

Tabel 4 Uji Reliabilitas E-Service Quality

\begin{tabular}{|c|c|}
\hline Cronbach's Alpha & N of Items \\
\hline 0,862 & 14 \\
\hline
\end{tabular}

Hasil uji reliabilitas yang di dapat nilai Cronbach's Alpha sebesar 0,862 dengan jumlah item sebanyak 14. Karena nilai 0,862 >0,6 maka dapat disimpulkan bahwa instrumen pada reliabilitas adalah reliabel.

Tabel 5 Uji Reliabilitas E-Customer Satisfaction

\begin{tabular}{|c|c|}
\hline Cronbach's Alpha & N of Items \\
\hline 0,874 & 14 \\
\hline
\end{tabular}

Hasil uji reliabilitas yang di dapat nilai Cronbach's Alpha sebesar 0,874 dengan jumlah item sebanyak 14. Karena nilai 0,874 >0,6 maka dapat disimpulkan bahwa instrumen pada reliabilitas adalah reliabel.

\subsection{Uji Normalitas Data}

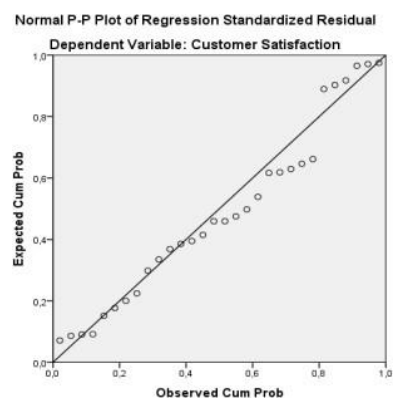

Gambar 2. Grafik Normal P-P Plot

Dari gambar 2 tampak bahwa data menyebar disekitar garis diagonal (tidak terpancar jauh dari garis lurus). Data menyebar di sekitar garis diagonal dan mengikuti arah diagonal menunjukkan bahwa model regresi memenuhi asumsi normalitas hal ini menjelaskan bahwa e-commerce customer satisfaction (Y) berdistribusikan normal, dikarenakan data yang terpancar pada garis diagonal tidak terpancar jauh dari garis lurus tersebut.

\subsection{Uji Linearitas}

Tabel 6 Uji Lienaritas

\begin{tabular}{|c|c|c|c|c|c|c|}
\hline \multicolumn{7}{|c|}{ ANOVA Table } \\
\hline & & $\begin{array}{l}\text { Sum of } \\
\text { Squares }\end{array}$ & df & $\begin{array}{l}\text { Mean } \\
\text { Square }\end{array}$ & $\mathrm{F}$ & Sig. \\
\hline \multirow{5}{*}{$\begin{array}{c}\text { Customer } \\
\text { Satisfactio } \\
\mathrm{n} * \\
\text { Service } \\
\text { Quality }\end{array}$} & & $\begin{array}{c}1,516,45 \\
0\end{array}$ & 19 & 79,813 & 4,884 & 0,007 \\
\hline & & 973,955 & 1 & 973,955 & $\begin{array}{c}59,59 \\
9 \\
\end{array}$ & 0,000 \\
\hline & & 542,495 & 18 & 30,139 & 1,844 & 0,162 \\
\hline & $\begin{array}{r}\text { Withi } \\
n \text { Groups }\end{array}$ & 163,417 & 10 & 16,342 & & \\
\hline & Total & $\begin{array}{c}1,679,86 \\
7\end{array}$ & 29 & & & \\
\hline
\end{tabular}

Dari tabel 5 di atas dapat diketahui bahwa nilai signifikansi sebesar 0,162 lebih besar dari 0,05, yang artinya terdapat hubungan yang linear secara signifikan antara variabel $e$ service quality $(\mathrm{X})$ dengan variabel e-customer satisfaction (Y). Sedangkan jika kita hitung dengan nilai f, diperoleh nilai fhitung $=1,844$, sedang ftabel kita cari pada distribution tabel nilai f0.05, dengan angka dfnya, dari output diatas diketahui df 18.10. Lalu kita cari pada ftabel ditemukan nilai ftabel $=2,41$. Karena nilai fhitung lebih kecil dari ftabel maka dapat disimpulkan bahwa terdapat hubungan linear secara signifikan antara variabel $e$-service quality $(\mathrm{X})$ dengan variabel e-customer satisfaction $(\mathrm{Y})$.

\subsection{Uji Heteroskedastisitas}

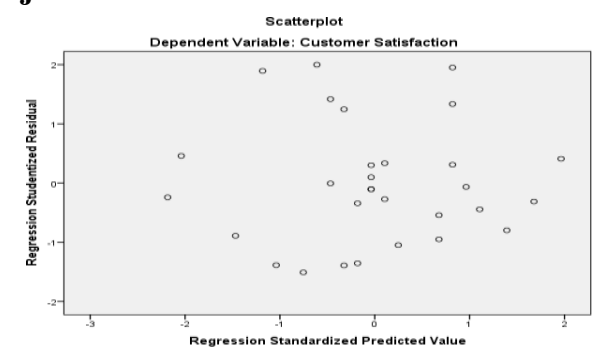

Gambar 3 Uji Heteroskedastisitas

Gambar 3 diatas merupakan gambar hasil uji heteroskedastisitas dimana diagram pancar yang ada tidak membentuk pola tertentu yang jelas, maka regresi pada penelitian ini tidak mengalami gangguan heteroskedastisitas.

4.7 Uji Koefisien Determinasi

Tabel 7 Uji Koefisien Determinasi

\begin{tabular}{|c|c|c|c|c|}
\hline \multicolumn{5}{|c|}{ Model Summary } \\
\hline $\begin{array}{r}\text { Mode } \\
\text { I }\end{array}$ & R & R Square & $\begin{array}{r}\text { Adjusted } \\
\text { R } \\
\text { Squar } \\
\mathbf{e}\end{array}$ & $\begin{array}{c}\text { Std. Error of the } \\
\text { Estimate }\end{array}$ \\
\hline 1 & $\begin{array}{r}0,76 \\
1\end{array}$ & 0,580 & 0,565 & 5,021 \\
\hline
\end{tabular}


Berdasarkan Tabel 6 menjelaskan tentang nilai korelasi sederhana $(\mathrm{R})$ sebesar 0,761 , koefisien determinasi $(R$ Square) sebesar 0,580, koefiensi determinasi yang disesuaikan (Adjusted $R$ Square) sebesar 0,565 dan ukuran kesalahan prediksi (Std Error of the estimate) sebesar 5,021. Dari output tabel 4.16 dapat diketahui nilai $R$ Square adalah 0,580. Jadi sumbangan pengaruh dari variabel independent yaitu $58 \%$ sedangkan sisanya $32,2 \%$ dipengaruhi oleh faktor lain yang tidak diteliti.

\subsection{Uji F}

Tabel 8 Uji F

\begin{tabular}{|c|c|c|c|}
\hline Model & Fhitung & Ftabel & Sig. \\
\hline Regression Residual & 38,632 & 4,170 & 0,000 \\
\hline
\end{tabular}

Berdasarkan tabel 7 diatas menunjukan bahwa $\mathrm{H}_{0}$ ditolak dan menerima $\mathrm{H}_{1}$, yaitu secara simultan (bersama-sama) variable independent berpengaruh signifikan terhadap variable dependent.

\subsection{Uji T}

Tabel 9 Uji T

\begin{tabular}{|l|r|r|r|l|l|}
\hline $\begin{array}{l}\text { Variabel } \\
\text { Independen }\end{array}$ & Thitung & Ttabel & Signifikan & Keterangan & Kesimpulan \\
\hline Reliabilitas & 6,215 & 1,697 & 0 & $\begin{array}{l}\text { thitung > t } \\
\text { tabel }\end{array}$ & $\begin{array}{l}\text { berpengaruh } \\
\text { signifikan }\end{array}$ \\
\hline
\end{tabular}

Berdasarkan tabel 8 di atas maka hasil yang diperoleh sebagai berikut E-service quality (X) nilai thitung sebesar 6,215 dengan nilai signifikan sebesar 0 . Karena thitung >ttabel $(6,215>1,697)$ atau sig $\mathrm{t}<5 \%(0<0,05)$ maka secara parsial variabel e-service quality (X) berpengaruh signifikan positif terhadap variabel $e$ customer satisfaction (Y).

\section{Kesimpulan}

Berdasarkan hasil analisis dan pembahasan mengenai pengaruh e-service quality terhadap e-customer satisfaction pada website kaosyay.com, maka dapat disimpulkan bahwa terdapat pengaruh positif e-service quality terhadap e-customer satisfaction pada website startup kaosyay. Hal ini menunjukan bahwa pengguna kaosyay.com meyakini kualitas pelayanan dari website kaosyay.com sangat berkualitas dan memberikan kompetensi yang baik sehingga dapat membantu pengguna pada saat ingin melakukan akses, transaksi pembelian dan pemesanan kaos secara online. Serta adanya ekspetasi kepuasan pelanggan dari para pengguna kaosyay dalam mengakses dan melakukan pembelanjaan kaos secara online. Sehingga untuk kedepannya website kaosyay dapat meningkatkan kualitas pelayanan dan menimbulkan adanya ekspetasi kepuasan pelanggan.

\section{DAFTAR PUSTAKA}

Acinkymailcom, E. (2017) 'PENGARUH E-SERVICE QUALITY DAN DISKON TERHADAP MINAT BELI PADA SITUS ONLINE DI WEBSITE Zalora.co.id DI SURABAYA', 1, pp. 15-18.

Akbar, A. A. and Djatmiko, T. (2016) 'Pengaruh E-Service
Quality Terhadap E-Customer Satisfaction Dan ECustomer Loyalty Pada Lazada.co.id', 3(1), pp. 142150.

Fandy, T. and Greorius, C. (2016) Service, Quality dan Satisfaction. 4th edn. Yogyakarta: ANDI Yogyakarta

Multiyaningsih E (2011) 'Riset Terapan Bidang Pendidikan \& Teknik'.

Prisanti, M. Della et al. (2017) 'PENGARUH E-SERVICE QUALITY DAN E-TRUST TERHADAP ECUSTOMER SATISFACTION SERTA IMPLIKASINYA TERHADAP ECUSTOMER LOYALTY', 2(1), pp. 19-38.

Siagian, H. and Cahyono, E. (2014) 'Analisis Website Quality , Trust Dan Loyalty Pelanggan Online Shop', Jurnal Manajemen Pemasaran, Vol. 8, No(2), pp. 5561. doi: 10.9744/pemasaran.8.2.55-61.

Sidharta, I. and Suzanto, B. (2015) 'Pengaruh Kepuasan Transaksi Online Shopping Dan Kepercayaan Konsumen Terhadap Sikap Serta Perilaku Konsumen Pada E-Commerce', Jurnal Computech \& Bisnis, 9(1), pp. 23-36.

Sugiyono,

$\mathrm{P}$.

D.

(2007)

STATISTIK_UNTUK_PENELITIAN_by_Prof._Dr..pdf . Edited by M. P. Dra. Endang Mulyatiningsih. Bandung: CV ALFABETA. 